\title{
Influence of Tomato Powder as Dietary Supplementation on Some Physiological, Biochemical and Histological Parameters in New Zealand White Growing Rabbits
}

\author{
Elwan, H.A.M. ${ }^{1}$; A.I. Zanouny ${ }^{1}$ and ${ }^{*}$ A.A. Abd El-Rahman ${ }^{2}$ \\ ${ }^{1}$ Animal and Poultry Production Department, Faculty of Agriculture, Minia University, Egypt. \\ ${ }^{2}$ Department of Agricultural Chemistry, Faculty of Agriculture, Minia University, Egypt. \\ *For correspondence: atefnagi2000@yahoo.com
}

Received on: $15 / 5 / 2018$

Accepted for publication on: 27/5/2018

\section{Abstract}

Tomato and tomato-by products contain some phytochemicals that may have health benefits and are important sources of many nutrients. Therefore, this study aimed to investigate the effect of two different concentrations ( 1 and $2 \%$ ) of tomato powder (TP) in diet of New Zealand white growing rabbits on some physiological, biochemical and histological parameters. Thirty unsexed New Zealand white growing rabbits (42 days old) were randomly assigned into 3 groups (10 rabbits each). The first group served as control (no additives). The second and the third groups were fed diets containing 1 and $2 \%$ tomato powder (TP), respectively, for 8 weeks. Results revealed that, no significant differences were observed in the absolute weights of some organs (kidney and thymus) and serum electrolyte concentrations $(\mathrm{Ca}, \mathrm{P}, \mathrm{K}, \mathrm{Na}$ ) between $\mathrm{TP}$ treated groups and control. Dietary 1 and 2\% TP supplementation induced alterations in serum biochemical parameters. Serum albumin $(\mathrm{g} / \mathrm{dl}), \mathrm{A} / \mathrm{G}$ ratio urea, uric acid and creatinine concentrations were significantly $(\mathrm{p}<0.05)$ decreased by TP administration ( 1 and $2 \%$ ), whereas globulin concentration $(\mathrm{g} / \mathrm{dl})$ was significantly $(\mathrm{p}<$ 0.05) increased compared to control group. Furthermore, no histopathological alterations were recorded in liver and kidney of TP treated groups. In conclusion, TP can be safely used in New Zealand white growing rabbits diet as natural growth enhancer.

Keywords: biochemical, histological, New Zealand white growing rabbit, physiological, tomato

\section{Introduction}

Tomatoes (Solanum lycopersicum) are one of the most broadly used vegetable crops. Tomato fruits is a healthful in the development of chronic degenerative disease which may be due to its containing antioxidant compounds (flavonoids and hydroxycinnamic acids) which decrease oxidative stress and scavenge free peroxyl radicals in the body (GarcíaValverde, et al., 2013; Ray et al., 2016). Detrimental effects of environmental stress could be partly consequent to induction of oxidative stress. Recent studies have been shown that, diets containing natural antioxidant substances could be used to attenuate the negative effects of environmental stress (Sahin and $\mathrm{Ku}-$ cuk, 2003; Sahin et al., 2008).

Tomatoes is a vegetable rich in carotenoids such as lycopene, carotene, phytoene, phytofluene, lutein and L-ascorbic acid (Soma, 2013; Marković et al., 2006). Lycopene is the major pigment $(\sim 87 \%)$ found in tomatoes and tomato products. It is an acyclic carotenoid compound contains 11 conjugated double bonds. 
Due to its antioxidant activity, it has engaged attention with other carotenoids and recently showed that, it is produced potent protection versus oxygen-induced cell damage (Marković et al., 2006). Moreover, polyphenols extracted from peel, pulp and seeds of tomatoes, have an antiproliferative effect in several cancer cell lines (Li et al., 2013). Specific strategies, such as use of chemical preservatives (Giménez et al., 2015), antioxidants addition (Realini et al., 2015) and feed systems adoption (Rossi et al., 2014) have been used to reduce or prohibit damage by oxidation. One of the most important strategies which used to improve animal lambs productivity is inclusion of phytochemicals in feed of animal lamps (Salem et al., 2014; Valdes et al., 2015). In search for new safe and effective phytochemicals which can improve the growth performance in rabbits, this study aimed to investigate the effect of tomato powder supplementation on physiological, biochemical and histological parameters of New Zealand white growing rabbits.

\section{Material and Methods}

\section{Preparation of tomato Powder}

Tomato was provided from a private commercial Farm at El-Minya Governorate Egypt. Then, oven dried on $50^{\circ} \mathrm{C}$ for $16 \mathrm{hrs}$ until constant weight. The dry tomato powder (TP) was finally milled, sieved (1 $\mathrm{mm}$ mesh) and stored for several days in a well tight polyethylene bags at room temperature $25^{\circ} \mathrm{C}$ until use.

\section{Experimental design}

Thirty unsexed New Zealand white growing rabbits (42-day old, $1350 \pm 150 \mathrm{~g})$ were randomly as- signed into three dietary groups (10 rabbits each) with supplementation of 0,1 and $2 \%$ tomato powder (TP) in diet, respectively, for 8 weeks. Animals were kept at the experimental rabbit farm site in the Department of Animal and Poultry Production, Faculty of Agriculture, Minia University. Then individually housed in cages $(35 \mathrm{x} 40 \mathrm{x} 40 \mathrm{~cm})$ in a controlled house (14 L:10 D and $18-24^{\circ} \mathrm{C}$ ) and fed a grower standard ration. The Experimental diets contents were as follows; protein $18 \%$, fiber $14 \%$, energy 2600 $\mathrm{kcal} / \mathrm{kg}, 44 \%$ ground yellow corn, $15.5 \%$ wheat bran, $25 \%$ sugar beet pulp, $13.5 \%$ soybean meal (44\% crude protein), $0.75 \%$ limestone, $0.5 \%$ sodium chloride and $0.75 \%$ premix (vitamins and minerals). Tomato powder was added and thoroughly hand mixed with other feed ingredients of each batch at 0,1 and $2 \%$. The basal experimental diets were formulated and pelleted to cover the nutrient requirements of rabbits according to National Research Council (NRC, 1977). Feed and water were provided ad libitum during the experimental period (8 weeks).

\section{Physiological response}

At the end of the experiment, ten rabbits from each group were fasted for 12 hrs before slaughtering, weighed and handily slaughtered and left complete bleeding. Slaughtered animals were de-skinned. Edible offal's (liver, kidneys, spleen and thymus) were separately weighed and recorded. All organs were determined to live body weights.

\section{Blood constituents}

Blood samples were collected by decapitation into test tubes without anticoagulant then centrifuged (K15 
Ultra cooling centrifuge, ENVAIR Deutschland $\mathrm{GmbH}$ ) at $3000 \mathrm{rpm}$ for 10 min; serum was collected and kept at $-20^{\circ} \mathrm{C}$ until analysis.

Determination of liver functions such as some liver enzymes and metabolites like; alanine aminotransferase (ALT), aspartate aminotransferase (AST) (Reitman and Frankel, 1957), alkaline phosphatase (ALP) (Babson, 1965), Gamma glutamyl transferase (GGT) (Rosalki et al. 1970), and lactate dehydrogenase (LDH) (Horecker and Kornberg 1948) were determined using diagnostic kits (Vitro, Germany). Also, total protein and albumin concentrations (Peters, 1968; Doumas et al., 1971) were determined using commercial kits (Bio-Med, Egypt). Serum globulin concentration and albumin /globulin (A/G) ratio were calculated using the following equations: Globulin $(\mathrm{g} / \mathrm{dl})=$ Total proteins $(\mathrm{g} / \mathrm{dl})$ - Albumin (g/dl). All analytical testes were done using T80 UV Spectrophotometer UK.

The serum was analyzed for levels of urea $(\mathrm{mg} / \mathrm{dl})$, uric acid $(\mathrm{mg} / \mathrm{dl})$, creatinine $(\mathrm{mg} / \mathrm{dl})$, creatinine kinase (U/l), using commercially BioMed reagent kits Egypt according to (Tietz, 1986, Tietz and Saunders 1990). While calcium (mg/dl), phosphate $(\mathrm{mg} / \mathrm{dl})$, potassium $(\mathrm{mmol} / \mathrm{L})$ and sodium $(\mathrm{mmol} / \mathrm{L})$ were determined using Vet scan VS2 Blood chemistry and electrolyte analyzer (ABAXIS Germany).

\section{Histopathological Examination}

Microscopic changes were observed through random selection of liver and kidney samples from each treatments and control animals. Tissues were preserved in $10 \%$ formalin followed by dehydration in ascending grades of alcohol. Clearing by xylene and embedding in paraffin wax. Paraffin sections $(5 \mu \mathrm{m}$ thickness $)$ were stained with hematoxylin and eosin $(H \& E)$ for histological examination.

\section{Statistical analysis}

Data were statistically analyzed by one-way ANOVA and Duncan's multiple range test, using the SAS software (Statistical analysis system, version 9.1.3, 2003). (Duncan, 1955). Comparison between the control and the treatments were considered statistically significant with $95 \%$ confidence interval $(\mathrm{P}<0.05)$.

\section{Results and Discussion}

\section{Absolute and relative weights of some organs}

The change in absolute and relative weights of liver, kidney, spleen and thymus were recorded for the rabbits of different groups and the results are presented in Table 1. Liver, kidney and thymus relative weights were significantly $(\mathrm{p}<0.05)$ decreased by the administration of 1 and $2 \%$ TP by $19.8,17.3,15.5,22.4$, 16.6 and $33.3 \%$ respectively compared to the control group. Nonsignificant decrease was observed in spleen relative weight among all groups. 
Table 1. Effect of tomato powder (TP) supplementation on live body weight, carcass and some organs absolute and relative weights of New Zealand white growing rabbits at 14 weeks of age.

\begin{tabular}{|l|c|c|c|}
\hline \multirow{2}{*}{} & \multicolumn{3}{|c|}{ Groups } \\
\cline { 2 - 4 } & Control & $\mathbf{1 \%}$ TP & 2\% TP \\
\hline Live body weight (g) & $2000.3 \pm 44.03^{\mathrm{b}}$ & $2667.3 \pm 14.76^{\mathrm{a}}$ & $2710.4 \pm 11.20^{\mathrm{a}}$ \\
\hline Carcass weight (g) & $1152.0 \pm 33.09^{\mathrm{b}}$ & $1328.1 \pm 11.22^{\mathrm{a}}$ & $1343.3 \pm 8.39^{\mathrm{a}}$ \\
\hline Liver weight (g) & $47.5 \pm 6.86^{\mathrm{b}}$ & $50.8 \pm 0.75^{\mathrm{b}}$ & $53.2 \pm 0.89^{\mathrm{a}}$ \\
\hline Liver (\%) & $2.3 \pm 1.55^{\mathrm{a}}$ & $1.9 \pm 0.03^{\mathrm{b}}$ & $1.9 \pm 0.03^{\mathrm{b}}$ \\
\hline Kidney weight (g) & $11.7 \pm 3.68$ & $13.1 \pm 0.45$ & $12.3 \pm 0.39$ \\
\hline Kidney (\%) & $0.5 \pm 0.83^{\mathrm{a}}$ & $0.4 \pm 0.01^{\mathrm{b}}$ & $0.4 \pm 0.01^{\mathrm{b}}$ \\
\hline Spleen weight (g) & $1.4 \pm 1.12^{\mathrm{b}}$ & $1.8 \pm 0.12^{\mathrm{a}}$ & $1.8 \pm 0.05^{\mathrm{a}}$ \\
\hline Spleen (\%) & $0.07 \pm 0.25$ & $0.06 \pm 0.004$ & $0.06 \pm 0.002$ \\
\hline Thymus weight (g) & $2.5 \pm 1.52$ & $2.8 \pm 0.20$ & $2.3 \pm 0.09$ \\
\hline Thymus (\%) & $0.1 \pm 0.34^{\mathrm{a}}$ & $0.1 \pm 0.007^{\mathrm{a}}$ & $0.08 \pm 0.003^{\mathrm{b}}$ \\
\hline
\end{tabular}

$1 \% \mathrm{TP}$, diet supplemented with $1 \%$ tomato powder; $2 \% \mathrm{TP}$, diet supplemented with $2 \%$ tomato powder. Values are presented as mean \pm SEM. One-way analysis of variance (ANOVA) and Duncan's multiple range test showed statistically significant differences in relation to the control at $\mathrm{p}<0.05$. Different letters in a row represent significant difference and the same letters or if no letters are shown in a row represent no significant difference.

These results in partially agreed with those obtained by Elkomy et al., (2016) who found that, there was a significant decrease in liver relative weight with increase dried tomato pomace (DTP) inclusion level. A similar study conducted by Sayed and Abdel-Azeem, (2009), revealed that, DTP can be safely used in rabbits diet up to $20 \%$. Also, the present study shows that, when TP ( 1 and $2 \%$ ) was fed to rabbits, live body weight and carcass weight were increased (Table $1)$. These results were in agreement with the study of Yitbarek, (2013), which showed that, DTP exposure by $5 \%$ in rhode island red grower chicks diet promoted increase in carcass yield values compared with other treatment groups. The effect of TP on body and carcass weight, as well as some organs in the present study may be due to containing TP a several types of carotenoids.

\section{Liver Function Tests (LFTs)}

As shown in Table 2, administration of TP (1 and 2\%) significantly depleted serum AST, GGT and LDH activities within the normal range (AST: 14-113 U/L, GGT: 2-50 U/L, LDH: 34-129 U/L) compared to the control group. Also, TP administration showed non-significant differences in ALT and ALP activities. This could be attributed to the improvement in liver functions in rabbits does to the potent antioxidant activities of lycopene and other carotenoids present in TP which may have contribution to prevent against oxidative stress (Zeb and Haq, 2016). In line with the present findings, Elkomy et al., (2016), revealed that, 10,15 and $20 \%$ of tomato pomace administration promoted a significant reduction in serum AST and ALT activities of growing rabbits. 
Website: www.aun.edu.eg/faculty_agriculture/journals_issues_form.php E-mail: ajas@aun.edu.eg

Table 2. Alterations in serum hepatic markers enzyme activities of New Zealand white growing rabbits at 14 weeks of age fed on tomato powder supplementation.

\begin{tabular}{|l|c|c|c|}
\hline & \multicolumn{3}{|c|}{ GROUPS } \\
\cline { 2 - 4 } & Control & $\mathbf{1 \%}$ TP & $\mathbf{2 \%}$ TP \\
\hline ALT (U/L) & $41.7 \pm 0.11$ & $40.9 \pm 0.60$ & $40.9 \pm 0.34$ \\
\hline AST (U/L) & $109.8 \pm 0.25^{\mathrm{a}}$ & $107.9 \pm 0.21^{\mathrm{b}}$ & $108.7 \pm 0.22^{\mathrm{b}}$ \\
\hline ALP (U/L) & $34.5 \pm 1.32$ & $34.0 \pm 0.40$ & $33.5 \pm 0.20$ \\
\hline GGT (U/L) & $5.1 \pm 0.02^{\mathrm{a}}$ & $4.1 \pm 0.04^{\mathrm{b}}$ & $4.5 \pm 0.08^{\mathrm{b}}$ \\
\hline LDH (U/L) & $124.1 \pm 0.73^{\mathrm{a}}$ & $100.2 \pm 0.85^{\mathrm{b}}$ & $101.8 \pm 1.73^{\mathrm{b}}$ \\
\hline
\end{tabular}

$1 \% \mathrm{TP}$, diet supplemented with $1 \%$ tomato powder; $2 \% \mathrm{TP}$, diet supplemented with $2 \%$ tomato powder. Values are presented as mean \pm SEM. One-way analysis of variance (ANOVA) and Duncan's multiple range test showed statistically significant differences in relation to the control at $\mathrm{p}<0.05$. Different letters in a row represent significant difference and the same letters or if no letters are shown in a row represent no significant difference.

Furthermore, the alterations of concentration of total proteins and their fractions in serum were recorded for the rabbits of different groups and the results are presented in Table 3. Tomato powder ( 1 and $2 \%)$ exposure significantly $(\mathrm{p}<0.05)$ decreased serum concentration of albumin $(\mathrm{g} / \mathrm{dl})$ and $\mathrm{A} / \mathrm{G}$ ratio by $29.5,39.2,56.3$ and
$65.1 \%$ respectively compared to the control group. Contrary, TP (1 and $2 \%$ administration significantly raised globulin concentration $(\mathrm{g} / \mathrm{dl})$ by 36.4 and $41.8 \%$, respectively. In addition, TP (1 and 2\%) treatment maintained serum total protein level similar to the control group.

Table 3. Alterations in serum protein profiles of New Zealand white growing rabbits at 14 weeks of age fed on tomato powder supplementation.

\begin{tabular}{|l|c|c|c|}
\hline \multirow{2}{*}{} & \multicolumn{3}{|c|}{ Groups } \\
\cline { 2 - 4 } & Control & $\mathbf{1 \%}$ TP & 2\% TP \\
\hline Total protein $(\mathrm{g} / \mathrm{dl})$ & $5.2 \pm 0.08$ & $5.6 \pm 0.04$ & $5.7 \pm 0.17$ \\
\hline Albumin $(\mathrm{g} / \mathrm{dl})$ & $3.0 \pm 0.08^{\mathrm{a}}$ & $2.1 \pm 0.05^{\mathrm{b}}$ & $1.3 \pm 0.04^{\mathrm{b}}$ \\
\hline Globulin $(\mathrm{g} / \mathrm{dl})$ & $2.2 \pm 0.11^{\mathrm{b}}$ & $3.5 \pm 0.06^{\mathrm{a}}$ & $3.8 \pm 0.20^{\mathrm{a}}$ \\
\hline Albumin/Globulin Ratio & $1.3 \pm 0.11^{\mathrm{a}}$ & $0.5 \pm 0.02^{\mathrm{b}}$ & $0.4 \pm 0.03^{\mathrm{b}}$ \\
\hline
\end{tabular}

$1 \% \mathrm{TP}$, diet supplemented with $1 \%$ tomato powder; $2 \% \mathrm{TP}$, diet supplemented with $2 \%$ tomato powder. Values are presented as mean \pm SEM. One-way analysis of variance (ANOVA) and Duncan's multiple range test showed statistically significant differences in relation to the control at $\mathrm{p}<0.05$. Different letters in a row represent significant difference and the same letters or if no letters are shown in a row represent no significant difference.

These findings conflict with the similar study, conducted by Elkomy et al., (2016), which revealed that, administration of different concentration of dried tomato pomace (DTP), to male rabbits diet induced an increase in serum total protein and albumin concentrations. These observed differences in protein profile may be due to various administrative concentrations of TP. Increase of serum globulin which play an important role in fighting infections within the normal range (1.5-3.8 g/dl) observed in the present study is a good indicator to improve the immune response by the administration of TP in rabbits diet. This seems to be due to preven- 
tive activity and antioxidant potential of $\beta$-carotene, lycopene and $\alpha$ tocopherol present in TP (Zeb and Haq, 2016).

\section{Kidney Function Tests (LFTs)}

Renal function analyses include creatine kinase $(\mathrm{U} / \mathrm{L})$, urea $(\mathrm{mg} / \mathrm{dl})$, uric acid $(\mathrm{mg} / \mathrm{dl})$ and creatinine $(\mathrm{mg} / \mathrm{dl})$ were determined in the present study to assess the safety of TP administration in rabbits diet on the kidney functions and the results are shown in Table 4. Tomato powder administration maintained serum creatine kinase $(\mathrm{U} / \mathrm{L})$ level close to control group, suggesting that TP has no deleterious effects on the kidneys. Whereas, TP (1 and 2\%) administration promoted a significant $(\mathrm{p}<0.05)$ decrease within the normal range in serum urea $(36.6-84.2 \mathrm{mg} / \mathrm{dl})$, uric acid $(1-4.3 \mathrm{mg} / \mathrm{dl})$ and creatinine $(0.5-2.5 \mathrm{mg} / \mathrm{dl})$ concentrations by $22.3,22.8,26.5,37.3,26,7$ and $41.1 \%$, respectively. Serum biochemical markers (urea, uric acid and creatinine) of renal functions are useful to evaluate the kidney health status and an increase in these markers may be associated with kidney disease (Mitchell and Kline, 2006). Decrease of serum urea, uric acid and creatinine within the normal range noted in the present study is a potent indicator to improve the kidney functions by $\mathrm{TP}$ administration in rabbits diet and could be due to the antioxidant defense of lycopene present in TP (Aydin et al., 2013).

Table 4. Alterations in kidney function testes of New Zealand white growing rabbits at 14 weeks of age fed on tomato powder supplementation.

\begin{tabular}{|l|c|c|c|}
\hline \multirow{2}{*}{} & \multicolumn{3}{|c|}{ GROUPS } \\
\cline { 2 - 4 } & Control & 1\% TP & 2\% TP \\
\hline Creatine kinase (U/L) & $118.0 \pm 2.85$ & $116.5 \pm 1.02$ & $115.2 \pm 0.60$ \\
\hline Urea $(\mathrm{mg} / \mathrm{dl})$ & $55.4 \pm 0.22^{\mathrm{a}}$ & $43.0 \pm 1.08^{\mathrm{b}}$ & $42.7 \pm 0.85^{\mathrm{b}}$ \\
\hline Uric Acid (mg/dl) & $3.3 \pm 0.06^{\mathrm{a}}$ & $2.4 \pm 0.02^{\mathrm{b}}$ & $2.1 \pm 0.04^{\mathrm{c}}$ \\
\hline Creatinine (mg/dl) & $1.4 \pm 0.02^{\mathrm{a}}$ & $1.0 \pm 0.04^{\mathrm{b}}$ & $0.8 \pm 0.02^{\mathrm{c}}$ \\
\hline
\end{tabular}

$1 \% \mathrm{TP}$, diet supplemented with $1 \%$ tomato powder; $2 \% \mathrm{TP}$, diet supplemented with $2 \%$ tomato powder. Values are presented as mean \pm SEM. One-way analysis of variance (ANOVA) and Duncan's multiple range test showed statistically significant differences in relation to the control at $\mathrm{p}<0.05$. No letters are shown in a row represent no significant difference.

\section{Serum electrolytes}

In order to confirm the results about biochemical markers of renal functions, analysis of serum electrolytes includes $\mathrm{Ca}(\mathrm{mg} / \mathrm{dl}), \mathrm{P}$ $(\mathrm{mg} / \mathrm{dl}), \quad \mathrm{K} \quad(\mathrm{mmol} / \mathrm{L}$ and $\mathrm{Na}$ $(\mathrm{mmol} / \mathrm{L})$ were determined in the current study to assess renal functions and metabolic biochemistry profiles
(Yousafzai et al., 2012). As shown in Table 5, the serum electrolytes level of New Zealand white growing rabbits fed on tomato powder were similar to control group, suggesting that TP has no harmful effects on the serum electrolytes thus on the kidney functions. 
Website: www.aun.edu.eg/faculty_agriculture/journals_issues_form.php E-mail:ajas@aun.edu.eg

Table 5. Alterations in serum electrolytes of New Zealand white growing rabbits at 14 weeks of age fed on tomato powder supplementation.

\begin{tabular}{|l|c|c|c|}
\hline \multirow{2}{*}{} & \multicolumn{3}{|c|}{ Groups } \\
\cline { 2 - 4 } & Control & $\mathbf{1 \%}$ TP & $\mathbf{2 \% ~ T P}$ \\
\hline $\mathrm{Ca}(\mathrm{mg} / \mathrm{dl})$ & $9.5 \pm 0.11$ & $9.9 \pm 0.08$ & $9.4 \pm 0.13$ \\
\hline $\mathrm{P}(\mathrm{mg} / \mathrm{dl})$ & $7.4 \pm 0.30$ & $7.6 \pm 0.08$ & $7.8 \pm 0.25$ \\
\hline $\mathrm{K}(\mathrm{mmol} / \mathrm{L})$ & $6.5 \pm 0.12$ & $6.1 \pm 0.07$ & $6.1 \pm 0.06$ \\
\hline $\mathrm{Na}(\mathrm{mmol} / \mathrm{L})$ & $154.6 \pm 1.03$ & $153.3 \pm 1.02$ & $154.0 \pm 2.27$ \\
\hline
\end{tabular}

$1 \% \mathrm{TP}$, diet supplemented with $1 \%$ tomato powder; $2 \% \mathrm{TP}$, diet supplemented with $2 \%$ tomato powder. Values are presented as mean \pm SEM. One-way analysis of variance (ANOVA) and Duncan's multiple range test showed statistically significant differences in relation to the control at $\mathrm{p}<0.05$. Different letters in a row represent significant difference and the same letters or if no letters are shown in a row represent no significant difference.

\section{Histopathological alterations}

In order to assess the safety of $\mathrm{TP}$ administration in rabbits diet on some organs, liver and kidney tissues were examined for histopathological alterations after 8 weeks of TP administration. As shown in Figure 1B and $\mathrm{C}$, respectively $\mathrm{TP}$ ( 1 and $2 \%$ ) treated groups have no pathological alterations and didn't differ from the control group (Figure 1A), showed normal hepatic cells and numerous hepatic lobules, the central vein is located in the middle of the lobule and the hepatocytes are polygonal in shape with granulated, eosinophilic cytoplasm and centrally located nuclei with one or two nucleoli and delicate strands of chromatin.
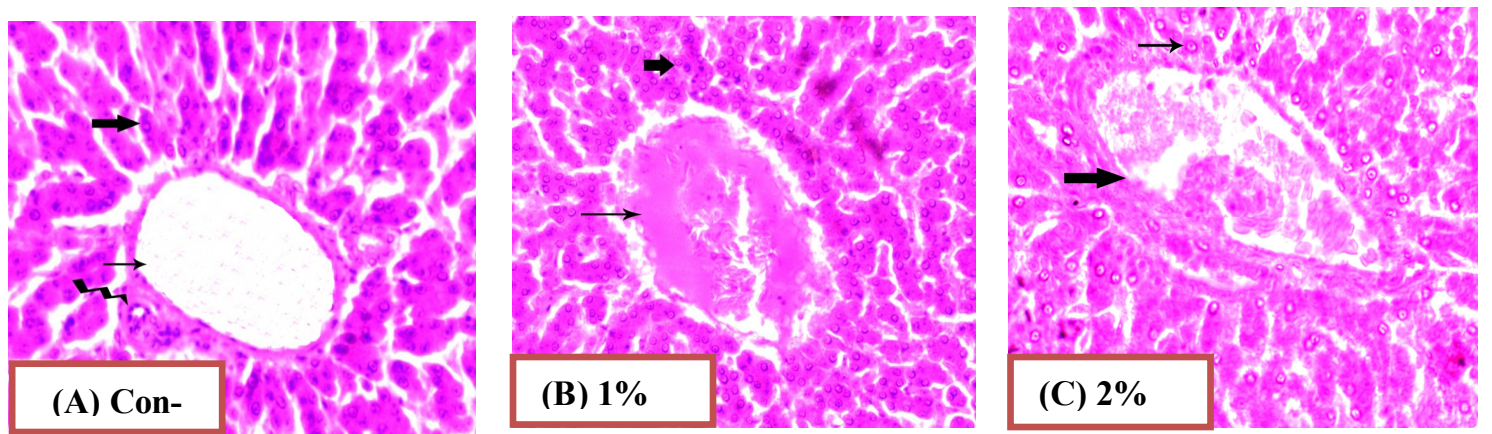

Figure (1): Histopathological examination of New Zealand white growing rabbits liver following the exposure of two different concentrations of tomato powder (TP) in diet for 8 weeks. (H\&E 40×). H\&E = Hematoxylin and eosin stained. (A): Control rabbits, (B): 1\% TP administrated group and (C): $2 \% \mathrm{TP}$ administrated group. Thick arrows showing numerous hepatic lobules, Thin arrows showing central vein is located in the middle.

In addition, analysis of sections of kidney from the TP (1 and $2 \%$ ) treated groups revealed that, no pathological alterations were observed and didn't differ from the control group (Figure 2A), showed outer cortex contains the renal corpuscles which appear as large spherical struc- ture and renal tubules. Each renal corpuscle is surrounded by the Bowman's capsule composed of simple squamous epithelial cells. It encloses the urinary space and the capillary tuft of the glomerulus which consists of blood capillaries. 


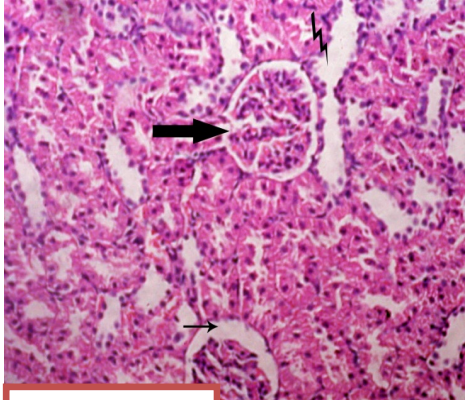

(A) Con-
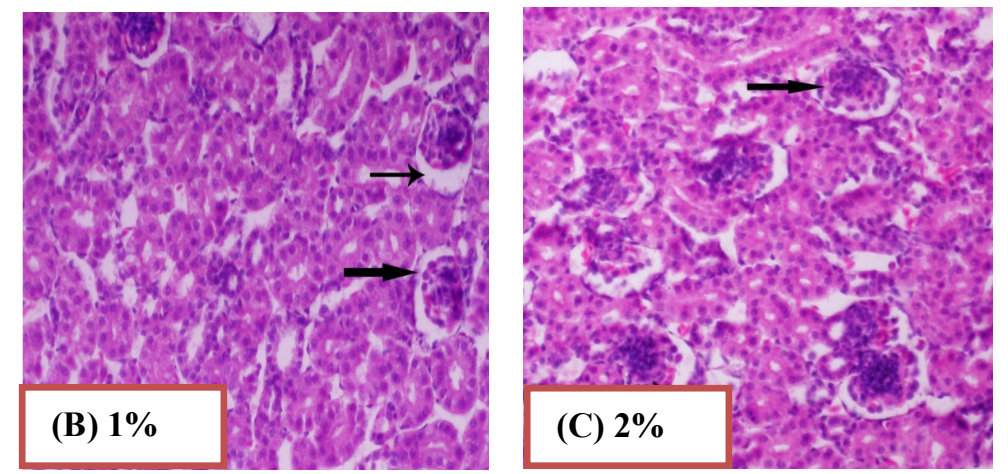

Figure (2): Histopathological examination of New Zealand white growing rabbit's kidney following the exposure of two different concentrations of tomato powder (TP) in diet for 8 weeks. (H\&E 40×). H\&E = Hematoxylin and eosin stained. (A): Control rabbits, (B): 1\% TP administrated group and (C): $2 \% \mathrm{TP}$ administrated group. Thick arrows showing renal corpuscle is surrounded by the Bowman's capsule composed of simple squamous epithelial cells.

In conclusion, the current study was conducted to assess the safety of tomato powder (TP) administration by 2 different concentrations ( 1 and $2 \%$ ) in rabbit's diet on some physiological, biochemical and histological parameters. It can be concluded from the results that, TP hasn't deleterious effects on the relative weights of some organs as well as liver and kidney functions. Furthermore, no pathological alterations were observed in rabbits' liver and kidney following the exposure of TP. Thus, TP can be considered safe to use in rabbit's diet as natural growth inducer. Further studies are needed to investigate the effect and mode of action of TP administration in animals.

\section{References}

Aydin S., Tokaç M., Taner G., Arikök A.T., Dündar H.Z., Ozkardes A.B., Taslipinar M.Y., Kiliç M., Basaran A.A., Basaran N. (2013). Antioxidant and antigenotoxic effects of lycopene in obstructive jaundice. Journal of Surgical Research, 82: 285-295.

Babson A.L. (1965). Phenolphthalein Monophosphate: A new substrate for alkaline phosphatase, Clinical Chemistry, 11: 789-795.

Doumas B.T., Watson W.A. and Biggs H.G. (1971). Albumin standards and the measurement of serum albumin with bromcresol green. Clinica Chimica Acta, 31: 87-96.

Duncan D.B. (1955). Multiple range and multiple $\mathrm{F}$ tests. Biometrics, 11:142.

Elkomy A.E., Zahran S.A., El-Azab A.I. and El- Azab M.A. (2016). Effects of substitution of alfalfa meal with dried tomato pomace (DTP) in New Zealand male rabbits rations on semen characteristics and some blood constituents. Pakistan Journal of Nutrition, 15: 590-599.

García-Valverde V., Navarro-Gonzalez I., Garcia-Alsonso J. and Periago M.J. (2013). Antioxidant bioactive compounds in selected industrial processing and fresh consumption tomato cultivars. Food and Bioprocess Technology, 6: 391-402.

Giménez B, Graiver N, Califano A, Zaritzky N. (2015). Physicochemical characteristics and quality parameters of a beef product subjected to chemical preservatives and high hydrostatic pressure. Meat Science, 100:179-188. 
Horecker B.L. and Kornberg A. (1948). The extinction coefficient of the reduced band of pyridine nucleotides. Journal of Biological Chemistry, 175: $385-390$.

Li F., Li S., Li H.B., Deng G.F., Ling W.H., Wu S., Xu X.R. and Chen F. (2013). Antiproliferative activity of peels, pulps and seeds of 61 fruits. Journal of Functional Foods, 5: 1298-1309.

Marković K., Hruškar M. and Vahčić N. (2006). Lycopene content of tomato products and their contribution to the lycopene intake of Croatians. Nutrition Research, 26: 556-560.

Mitchell H.R. and Kline W. (2006). Core curriculum in nephrology, renal function testing. American Journal of Kidney Diseases, 47: 174-183.

Peters T. (1968). Proposals for standardization of total protein assays. Clinical Chemistry, 14: 1147.

Ray S., Saha R., Raychaudhuri U. and Chakraborty R. (2016). Different quality characteristics of tomato (Solanum lycopersicum) as a fortifying ingredient in food products: A review. Technical Sciences, 19: 199-213.

Realini C.E., Guàrdia M.D., Díaz I., García-Regueiro J.A., Arnau J. (2015). Effects of acerola fruit extract on sensory and shelf-life of salted beef patties from grinds differing in fatty acid composition. Meat Science, 99:18-24.

Reitman S. and Frankel S. (1957). Colorimetric of serum transaminases. American Journal of Clinical Pathology, 28:56.

Rosalki S.B., Rav D., Lehman D., and Prentice M. (1970). Determination of serum gamma glutamyl trans peptidase activity and its clinical applications. Annals of Clinical Biochemistry, 7:143-147.
Rossi R., Ratti S., Pastorelli G., Crotti A., Corino C. (2014). The effect of dietary vitamin $\mathrm{E}$ and verbascoside on meat quality and oxidative stability of Longissimus dorsi muscle in medium-heavy pigs. Food Research International, 65:88-94.

Sahin K., and Kucuk O. (2003). Heat stress and dietary vitamin supplementation of poultry diets. Nutrition Abstracts and Reviews Series B: Livestock Feeds and Feeding, 73:41-50.

Sahin N., Orhan C., Tuzcu M., Sahin K., and Kucuk O. (2008). The effects of tomato powder supplementation on performance and lipid peroxidation in Quail. Poultry Science, 87:276-283.

Salem A.Z.M., Kholif A.E., Olivares M., Elghandour M.M.Y., Mellado M., Arece J. (2014). Influence of Salix babylonica extract on feed intake, growth performance and diet in vitro gas production profile in young lambs. Trop Tropical Animal Health and Production, 46: 213219.

Sayed A.N. and Abdel-Azeem A.M. (2009). Evaluation of dried tomato pomace as Feedstuff in the diets of growing Rabbits. International Journal for Agro Veterinary and Medical Sciences, 3: 12-18.

Soma S. (2013). Development and evaluation of antioxidant activity of tomato-based confectionary. International Food Research Journal, 20: 3167-3170.

Tietz N.W. (1986). Textbook of clinical chemistry. W. B. Saunders, Philadelphia, p 1271- 1281.

Tietz N.W., and Saunders W.B. (1990). Clinical guide to laboratory tests: $2^{\text {nd }}$ ed. Philadelphia: 26-29.

Valdes K.I., Salem A.Z.M., Lopez S., Alonso M.U., Rivero N., Elghandour M.M.Y., Domínguez I.A., Ronquillo M.G. and Kholif 
A.E. (2015). Influence of exogenous enzymes in presence of Salix babylonica extract on digestibility, microbial protein synthesis and performance of lambs fed maize silage. The Journal of Agricultural Science Cambridge, 153:732-742.

Yitbarek M.B. (2013). Carcass characteristics of Rhode Island Red (RIR) grower chicks feed on different levels of dried tomato pomace (DTP). International Journal of Advanced Research, 1: 17-22.
Yousafzai A., Ara S., Javed F., Jahan N., Ahmed N., Waseem M. and Asif M. (2012). Kidney function tests and serum electrolyte disorders in different ethnic groups of balochistan. BUITEMS Quality \& Excellence in Education, 22:164-169.

Zeb A. and Haq I. (2016). The protective role of tomato powder in the toxicity, fatty infiltration and necrosis induced by oxidized tallow in rabbits. Journal of Food Biochemistry, 40: 428-435. 
تأثير مسحوق الطماطم كمكل غذائي على بعض القياسات الفسيولوجية والبيوكيميائية

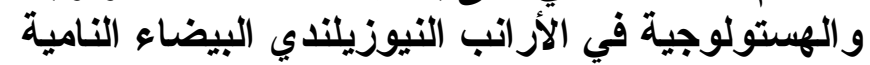

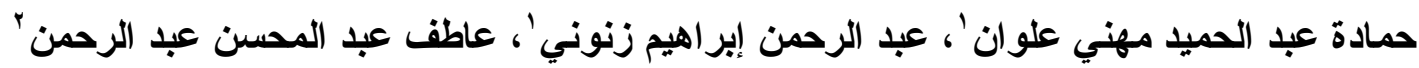

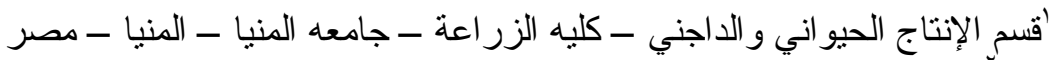

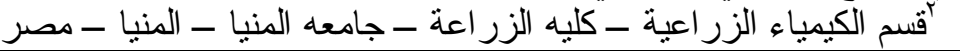

الملخص

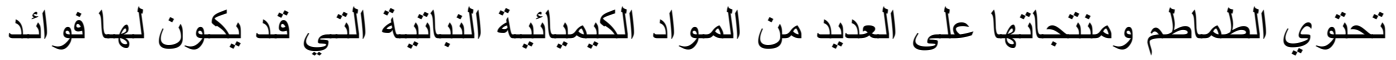

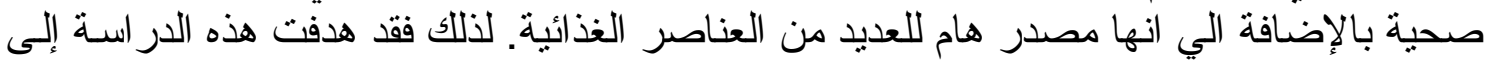

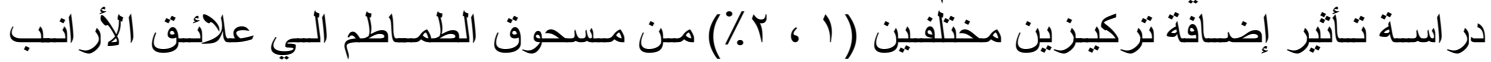

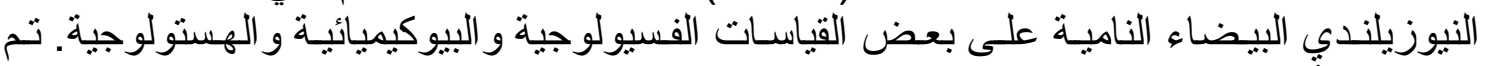

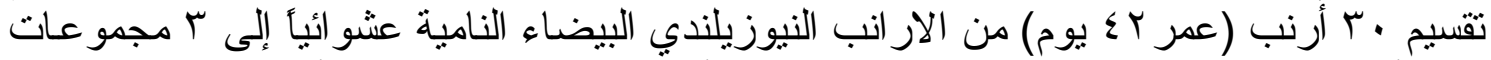

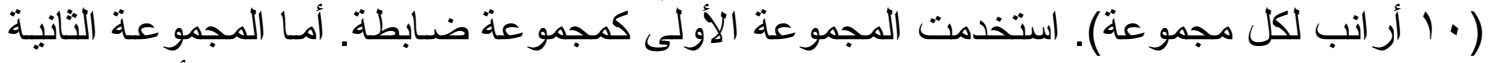

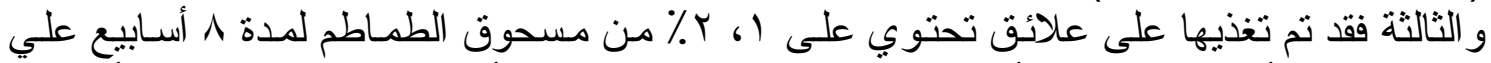

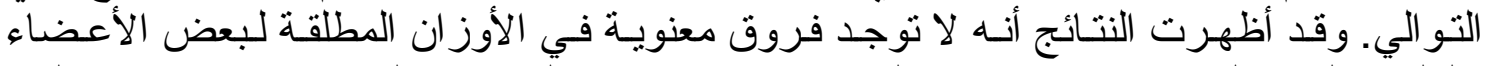

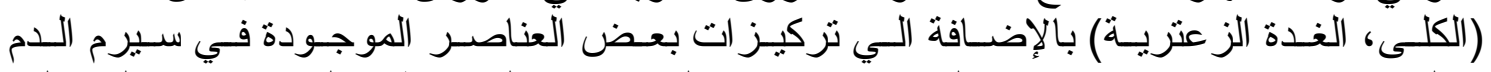

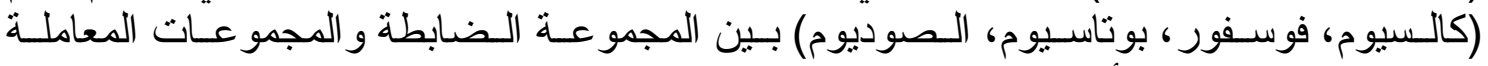

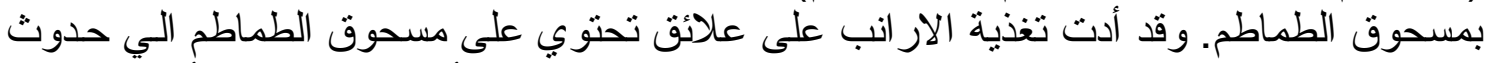

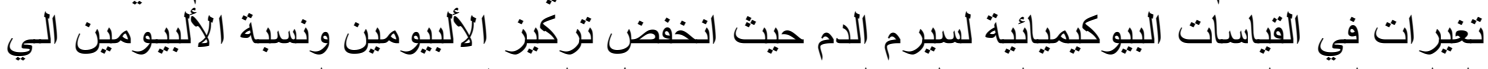

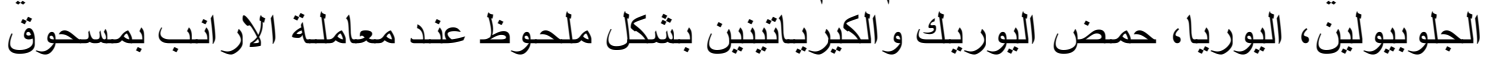

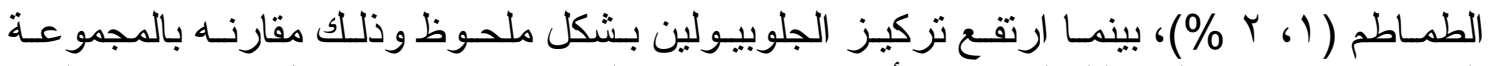

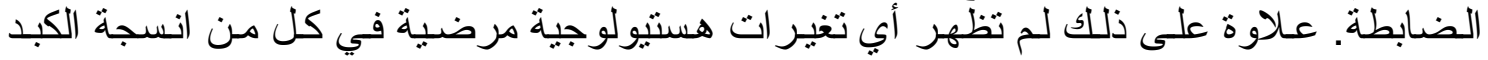

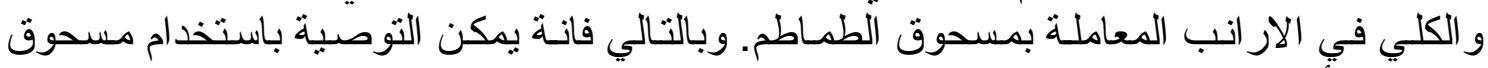
الطماطم بأمان في علائق الار انب النيوزيلندي البيضاء النامية كمحن نمو طبيعي. 